ISSN 1678-3921

Journal homepage: www.embrapa.br/pab

For manuscript submission and journal contents, access: www.scielo.br/pab

\section{Growth and essential oil content of accessions of Lippia rotundifolia in Minas Gerais, Brazil}

\begin{abstract}
The objective of this work was to evaluate the growth and essential oil content after transplantation and cutting of Lippia rotundifolia accessions from a natural population from the state of Minas Gerais, Brazil. Eight accessions were evaluated (PVP, GIG, RPE, ODA, JFE, PRP, SGS, and RTI) in six periods $(60,81,102,123,144$, and 165 days after transplanting and cutting), in a completely randomized experimental design. The following parameters were assessed: average width and length of the basal, median, and apical pair of leaves; plant height; stem diameter; and number of leaves. At 165 days, the yield of essential oil and the fresh and dry phytomass of the aerial part were also evaluated. Sixty days after the last evaluation, regrowth was measured from height, stem diameter, and number of leaves. The JFE accession stands out for emission of leaves, with a better development at 165 days after transplanting. RPE and PRP respond well to regrowth at 102 and 123 days after cutting, respectively. The SGS accession shows a high essential oil yield of $2.2 \%$, and PVP, a low yield of $0.3 \%$.
\end{abstract}

Index terms: agronomic behavior, germplasm, medicinal plant, rosemary.

\section{Crescimento e teor de óleo essencial de acessos de Lippia rotundifolia em Minas Gerais, Brasil}

Resumo - O objetivo deste trabalho foi avaliar o crescimento e o teor de óleo essencial após transplantio e corte de acessos de Lippia rotundifolia provenientes de população natural do estado de Minas Gerais, Brasil. Avaliaram-se oito acessos (PVP, GIG, RPE, ODA, JFE, PRP, SGS e RTI), em seis períodos $(60,81,102,123,144$ e 165 dias após transplantio e corte), em delineamento experimental inteiramente casualizado. Foram avaliados os seguintes parâmetros: largura média e comprimento do par de folhas basal, mediano e apical; altura da planta; diâmetro do caule; e número de folhas. Aos 165 dias, também avaliaram-se produção de óleo essencial e fitomassa fresca e seca da parte aérea. Sessenta dias após a última avaliação, mensurou-se a rebrota a partir de altura, diâmetro do caule e número de folhas. O acesso JFE se destaca na emissão de folhas, com melhor desenvolvimento aos 165 dias após o transplantio. RPE e PRP respondem bem à rebrota aos 102 e 123 dias após o corte, respectivamente. O acesso SGS apresenta alta produção de óleo essencial de $2,2 \%$, e o PVP, baixa produção de $0,3 \%$.

Termos para indexação: comportamento agronômico, germoplasma, planta medicinal, rosmaninho. 


\section{Introduction}

Lippia rotundifolia Cham., popularly known as rosemary, is a shrub species from the Verbenaceae family, with a height of 0.5 to $2.0 \mathrm{~m}$, native to the Brazilian Cerrado and endemic to the rock fields of the Cadeia do Espinhaço mountain chain (Sousa et al., 2013). The presence of this species in rocky outcrops is due to its low nutritional demand and reserve accumulation in xylopodium, which makes it resistant to fire and prolonged droughts (Taiz et al., 2017). Discovered in the eighteenth century, the plant is aromatic and used to produce essential oils (Salimena \& Múlgura, 2015).

Concentrated in its leaves and flowers, the essential oils of this species are chemically composed of myrcene, limonene, linalool, and caryophyllene (Meira et al., 2019a). The concentration of these active principles in oil extracts confirms the medicinal properties of the plant, which has antimicrobial action against the Escherichia coli and Staphylococcus aureus enterobacteria (Souza et al., 2015). Therefore, the species has potential for applications in traditional medicine, as well as in phytotherapy, aromatherapy, and the food market (Azevedo et al., 2017; Costa et al., 2017).

To produce the secondary metabolites required for these different uses, it is necessary to select specimens of good genetic origins, especially in the case of littleknown native species, such as L. rotundifolia. Among the many challenges involved are the difficulties in accessing these plants in a natural environment and in obtaining their seedlings through sexual propagation, since their seeds are very small and have a low germination of 25\% (Meira et al., 2016).

Vegetative propagation is the easiest way to obtain $L$. rotundifolia seedlings. Both micropropagation and greenhouse cultivation by cutting have already been carried out, showing that this plant has a high resilience capacity and potential for the production of essential oils (Resende et al., 2015; Hsie et al., 2019; Meira et al., 2019a). Of the two mentioned techniques, the cutting method stands out because it requires little technology and is more accessible.

Even though the species is grown mostly under protected cultivation, many factors can still affect its productive performance. Among them are edaphic and climatic conditions, besides the genetic factor, which allows plants to respond differently to the same cultivation conditions, at a same site, due to the phenotypic plasticity caused by changes in gene expression (Kumar et al., 2010; Meira et al., 2019b). This can interfere in the phenology of the species, as well as in the product obtained after harvest (Souza et al., 2007; Hartl \& Clark, 2010; Souza et al., 2014).

The objective of this work was to evaluate the growth and essential oil content after transplanting and cutting of Lippia rotundifolia accessions from a natural population from the state of Minas Gerais, Brazil.

\section{Materials and Methods}

The experiment was conducted from June 2015 to May 2016 at Instituto de Ciências Agrárias of Universidade Federal de Minas Gerais (ICA/UFMG), in the municipality of Montes Claros, in the state of Minas Gerais, Brazil (16²4'50.92"S, 4350'22.36"W, at an altitude of $650 \mathrm{~m}$ ). According to Köppen-Geiger, the climate of the region is Aw (tropical) and has two well-defined seasons: a dry winter and a rainy summer, with an annual average temperature of $23.1^{\circ} \mathrm{C}$ and an average annual precipitation of $869 \mathrm{~mm}$ (IBGE, 2021).

The seedlings of $L$. rotundifolia were obtained from specimens that occur naturally in the following eight fragments of the Cadeia do Espinhaço mountain chain, located in Minas Gerais: Parque Estadual Veredas do Peruaçu (PVP), comunidade Gigante (GIG), Rio do Peixe (RPE), Área de Preservação Permanente Olhos D’água (ODA), municipality of Joaquim Felício (JFE), Parque Estadual do Rio Preto (PRP), district of São Gonçalo do Rio das Pedras (SGS), and Corrêgo do Tigre (RTI). These occurrence sites were identified using the Oregon 550 global positioning system (Garmin, São Paulo, SP, Brazil), and their coordinates, soil types, altitude, temperature, and precipitation are shown in Table 1.

The accessions were registered in Sistema Nacional de Gestão do Patrimônio Genético e do Conhecimento Tradicional Associado (SisGen) under number A05B21D. The exsiccates of the specimens from each occurrence site were deposited in the herbarium of Empresa de Pesquisa Agropecuária de Minas Gerais, under records PAMG58090, PAMG58091, PAMG58092, PAMG58093, PAMG58094, PAMG58095, PAMG58097, and PAMG58100. 
For vegetative propagation, apical cuttings with 15 $\mathrm{cm}$ of length and three pairs of leaves each were planted in a polypropylene tray containing the Plantmax commercial substrate (Eucatex S/A Indústria e Comércio, São Paulo, SP, Brazil) and kept in a rooting bed until transplantation. At 60 days, the cuttings were transplanted to $1.5 \mathrm{dcm}^{3}$ pots containing Cerrado soil and tanned cattle manure at a ratio of 3:1. The seedlings were kept in a greenhouse at ICA/UFMG, covered with a $50 \%$ black-polyethylene shade net.

The soils of the sites are shown in Table 1 and were classified according to the Brazilian soil classification system (Santos et al., 2018). The soil samples used as substrate for cultivation after transplantation and after cutting were analyzed in the Soil Laboratory of ICA/ UFMG. The analyses were carried out according to the extraction and determination margins proposed by Ribeiro et al. (1999). The samples showed the following chemical characteristics: $\mathrm{pH}\left(\mathrm{H}_{2} \mathrm{O}\right) 7.7,80.1 \mathrm{mg} \mathrm{dm}^{-3} \mathrm{P}$ (Mehlich), $67.9 \mathrm{mg} \mathrm{dm}^{-3} \mathrm{~K}, 8.9 \mathrm{cmol}_{\mathrm{c}} \mathrm{dm}^{-3} \mathrm{Ca}^{2+}, 2.6 \mathrm{Mg}^{2+}$ $\mathrm{cmol}_{\mathrm{c}} \mathrm{dm}^{-3}, 0 \mathrm{cmol}_{\mathrm{c}} \mathrm{dm}^{-3} \mathrm{Al}^{3+}$ (exchangeable acidity), $0.76 \mathrm{cmol}_{\mathrm{c}} \mathrm{dm}^{-3} \mathrm{H}+\mathrm{Al}$ (potential acidity), sum of bases of $13.2 \mathrm{cmol}_{\mathrm{c}} \mathrm{dm}^{-3}$, effective cation exchange capacity of $13.2 \mathrm{cmol}_{\mathrm{c}} \mathrm{dm}^{-3}$, aluminum saturation of $0 \%$, cation exchange capacity at $\mathrm{pH} 7.0$ of $14 \mathrm{cmol}_{\mathrm{c}} \mathrm{dm}^{-3}$, base saturation of $95 \%, 8.61 \mathrm{~g} \mathrm{~kg}^{-1}$ organic matter, $8.5 \mathrm{~g} \mathrm{~kg}^{-1}$ coarse sand, $67.5 \mathrm{dag} \mathrm{kg}^{-1}$ fine sand, 16 dag kg-1 silt, and $8.00 \mathrm{dag} \mathrm{kg}^{-1}$ clay.

The experiment was conducted in two stages: after transplanting and after regrowth, with daily manual irrigation starting in summer. The experimental design was completely randomized in an $8 \times 7 \times 6$ factorial arrangement, with eight accessions, seven plants per accession, and six evaluation periods (60, $81,102,123,144$, and 165 days after transplanting and cutting) for each step. For all periods in both stages, the following nondestructive parameters were evaluated: average width and length of the basal, median, and apical pair of leaves; plant height; stem diameter; and number of leaves. In the last period of the first stage, corresponding to 165 days after transplanting, destructive parameters were analyzed, including shoot weight and essential oil yield. For these analyses, the aerial part of the plant was cut to $10 \mathrm{~cm}$ above ground. After cutting, the vessels of all accessions received $1 / 3$ of tanned manure for the emission of shoots. In the second stage, the assessment of the nondestructive regrowth parameters began at 225, 246, 267, 288, 309, and 330 days after transplanting; the first observation was carried out 60 days after cutting in the last evaluation period, followed by observations at 21-day intervals until 165 days of regrowth, corresponding to 225 days of cultivation.

To obtain the essential oil, the fresh vegetable material was homogenized, divided into three portions of $50 \mathrm{~g}$ each, and subjected to hydrodistillation using the TE-2762 essential oil distiller with a $1,000 \mathrm{~mL}$ glass flask of round bottom (Tecnal, Piracicaba, SP, Brazil), to which $2 / 3$ distilled water were added. The extraction process lasted 3 hours, and then the essential oil was collected from the water with the aid of a micropipette. The plant material resulting from hydrodistillation was maintained under forced-air circulation, at $65^{\circ} \mathrm{C}$, until reaching constant weight, in order to obtain dry

Table 1. Occurrence site and characterization of eight accessions of Lippia rotundifolia.

\begin{tabular}{|c|c|c|c|c|c|c|}
\hline \multirow[t]{2}{*}{ Accession $^{(1)}$} & \multicolumn{2}{|c|}{ Coordinate } & \multirow[t]{2}{*}{ Soill $^{(2)}$} & \multirow{2}{*}{$\begin{array}{l}\text { Altitude } \\
\text { (m) }\end{array}$} & \multirow{2}{*}{$\begin{array}{l}\text { Precipitation } \\
\quad(\mathrm{mm})\end{array}$} & \multirow{2}{*}{$\begin{array}{c}\text { Temperature } \\
\left({ }^{\circ} \mathrm{C}\right)\end{array}$} \\
\hline & Latitude & Longitude & & & & \\
\hline PVP & $-14^{\circ} 55^{\prime} 24^{\prime \prime S}$ & $-44^{\circ} 38^{\prime} 21^{\prime \prime} \mathrm{W}$ & LVAd & 729 & 700 & $22-24$ \\
\hline GIG & $-16^{\circ} 35^{\prime} 24^{\prime \prime S}$ & $-42^{\circ} 55^{\prime} 30^{\prime \prime} \mathrm{W}$ & $\mathrm{AR}$ & 726 & $1.200-1.500$ & $21-24$ \\
\hline RPE & $-16^{\circ} 52^{\prime} 36^{\prime \prime S}$ & $-43^{\circ} 28^{\prime} 56^{\prime \prime} \mathrm{W}$ & $\mathrm{AR}$ & 722 & $1.000-1.200$ & $21-24$ \\
\hline ODA & $-17^{\circ} 26^{\prime} 10^{\prime \prime S}$ & $-43^{\circ} 37^{\prime} 12^{\prime \prime} \mathrm{W}$ & $\mathrm{AR}$ & 691 & $1.000-1.200$ & $21-24$ \\
\hline JFE & $-17^{\circ} 44^{\prime} 24^{\prime \prime S}$ & $-44^{\circ} 11^{\prime} 41^{\prime \prime} \mathrm{W}$ & RLd & 1.010 & $1.200-1.500$ & $21-24$ \\
\hline PRP & $-18^{\circ} 06^{\prime} 09^{\prime \prime S}$ & $-43^{\circ} 20^{\prime} 18^{\prime \prime} \mathrm{W}$ & $\mathrm{AR}$ & 901 & $1.200-1.500$ & $18-19$ \\
\hline SGS & $-18^{\circ} 25^{\prime} 51^{\prime \prime S}$ & $-43^{\circ} 28^{\prime} 56^{\prime \prime} \mathrm{W}$ & $\mathrm{AR}$ & 1.020 & $1.200>1.500$ & $14.4-21$ \\
\hline RTI & $-19^{\circ} 16^{\prime} 147^{\prime \prime S}$ & $-43^{\circ} 37^{\prime} 12^{\prime \prime} \mathrm{W}$ & RLd & 756 & 1.600 & $19-21$ \\
\hline
\end{tabular}

(1)PVP, Parque Estadual Veredas do Peruaçu; GIG, comunidade Gigante; RPE, Rio do Peixe; ODA, Área de Preservação Permanente Olhos D’água; JFE, municipality of Joaquim Felício; PRP, Parque Estadual do Rio Preto; SGS, district of São Gonçalo do Rio das Pedras; and RTI, Corrêgo do Tigre. ${ }^{(2)}$ LVAd, Latossolo Vermelho-Amarelo distrófico; AR, rocky outcrop; and RLd, Neossolo Litólico distrófico. Soil classification according to Santos et al. (2018). Source: Meira et al. (2019b). 
biomass. The essential oil content was expressed as percentage based on the dry matter of the sample used in the extraction.

In order to enable statistics and to make the obtained values more homogeneous, the results of all variables were previously transformed into arcsine $(\mathrm{x} / 100)^{0.5}$. Subsequently, the quantitative data were subjected to the analysis of variance. The averages that showed significance based on the F-test were compared by Tukey's test, at 5\% probability. Growth data as a function of cultivation and post-harvest were also subjected to regression analysis $(\mathrm{p}<0.05)$ with the aid of the SAEG system for statistical analysis (Ribeiro Júnior, 2001).

\section{Results and Discussion}

The differences between genotypes allow evaluating the survival capacity of individuals in ex situ conditions (Hartl \& Clark, 2010), showing the importance of the observed results for species conservation.

For width of leaves, most accessions showed cubic behavior, except PVP, RTI, and RPE, which presented quadratic behavior (Figure $1 \mathrm{~A}$ ). The leaves of the PVP accession did not show a significant growth in width, which varied between 0.5 and $1.0 \mathrm{~cm}$, but had a longer length of $3.5 \mathrm{~cm}$. The opposite was found for the leaves of RTI, which were rounded, with an average width of $1.3 \mathrm{~cm}$ and an average length of $1.5 \mathrm{~cm}$ (Figure $1 \mathrm{~B}$ ). The RPE and ODA accessions presented narrow leaves, with a width of $0.4 \mathrm{~cm}$, whereas PRP had the widest leaves with $1.8 \mathrm{~cm}$. The remaining accessions presented median widths (Figure $1 \mathrm{~A}$ ).

In general, the length of the leaves of the accessions ranged from $0.49 \mathrm{~cm}$ for RPE to $3.0 \mathrm{~cm}$ for ODA and PRP (Figure $1 \mathrm{~B}$ ). The symmetry observed in the leaves in terms of width and length characterizes well the species, whose conformation justifies taxonomically its binomial rotundifolia. The longer leaves, according to Cabral et al. (2018), may be related to the adaptive behavior of the accessions, which developed phenotypic plasticity as an evolutionary mechanism to adapt to their natural environment over time. This result is in alignment with that obtained by Souza et al. (2007) and Martins et al. (2013), who reported the occurrence of leaf expansion in several species due to a lower light radiation caused by protected cultivation.
As for plant architecture, all accessions presented an upright-prostrate habit. Plant height varied according to the cultivation period and the studied accessions (Figure 2 A). The GIG accession showed a better response, with quadratic behavior in the first three evaluations at 60,81 , and 102 days; the highest height of $29.4 \mathrm{~cm}$ was verified at 102 days. ODA, however, presented linear behavior, with a higher height of $62 \mathrm{~cm}$ in the last evaluation at 165 days after transplantation (Figure $2 \mathrm{~A}$ ); a similar result was found in the natural environment. The higher height of this last accession can be explained by the fact that it was the only specimen located on a riverbed, which increased water availability and contributed to its better vegetative growth.

Regarding regrowth, the highest heights were of: 44 and $58 \mathrm{~cm}$ for the RPE accession in the first two evaluations; and $69 \mathrm{~cm}$ for PRP in the other periods, with a better development at 102 days (Figure 3 A). The leaves of the RTI accession showed the slowest development in all assessments, with a height of $17 \mathrm{~cm}$ at the beginning of the evaluation and of $34 \mathrm{~cm}$ at 81 days (Figure 3 A). This plant behavior is similar to that reported by Santos et al. (2006), who obtained higher essential oil yields and leaf dry matter for Lippia alba (Mill.) N.E.Br. in the first harvest, when plants were cut at a height of $45 \mathrm{~cm}$. However, it should be noted that, among the species of the same genus, $L$. alba is already considered domesticated due to its traditional cultivation in backyards, differently from wild species such as L. rotundifolia, whose exploitation should take into account its ecophysiological response, especially since it has not yet undergone domestication not even by genetic improvement.

For stem diameter, all accessions showed quadratic behavior during the vegetative growth phase (Figure $2 \mathrm{~B}$ ). The RPE accession presented the smallest diameter, which stabilized at $3.40 \mathrm{~cm}$. ODA and RTI had the largest diameters of 6.10 and $6.01 \mathrm{~mm}$ in the last evaluation at 165 days. The GIG accession showed good performance during regrowth, because it thickened constantly over time, starting at $0.18 \mathrm{~mm}$ at 60 days and reaching $0.34 \mathrm{~mm}$ at 165 days (Figure $3 \mathrm{~B}$ ). The other accessions presented quadratic behavior. JFE stood out with $0.28 \mathrm{~mm}$ at 81 days, whereas PRP had a greater thickness of $0.26 \mathrm{~mm}$ at 102 days. The PVP, SGS, and RTI accessions showed a better growth in diameter at 123 days, with averages of $0.24,0.27$, and $0.20 \mathrm{~mm}$. Although RTI had a good development

Pesq. agropec. bras., Brasília, v.56, e02406, 2021

DOI: 10.1590/S1678-3921.pab2021.v56.02406 
in the vegetative stage, with a leaf diameter of $6.01 \mathrm{~cm}$ at 165 days (Figure $2 \mathrm{~B}$ ), it did not respond well during regrowth, with a diameter of only $0.20 \mathrm{~mm}$, the lowest value for this parameter (Figure $3 \mathrm{~B}$ ).

The obtained results allow inferring that, during the vegetative stage, the species presented diameters ranging from $2.91 \mathrm{~mm}$ for RPE up to $6.0 \mathrm{~mm}$ for ODA and RTI (Figure 2 B). However, when the species was subjected to pruning events under protected cultivation, the thicknesses of the branches produced by the lateral buds varied from $0.19 \mathrm{~mm}$ for RTI to $0.34 \mathrm{~mm}$ for GIG (Figure $3 \mathrm{~B}$ ); the exception was ODA, which presented a single rod of $1.32 \mathrm{~mm}$ after cutting. Therefore, this analysis emphasizes that even if diameter varies between accessions, it is more developed in the main stem. Duarte et al. (2002) found
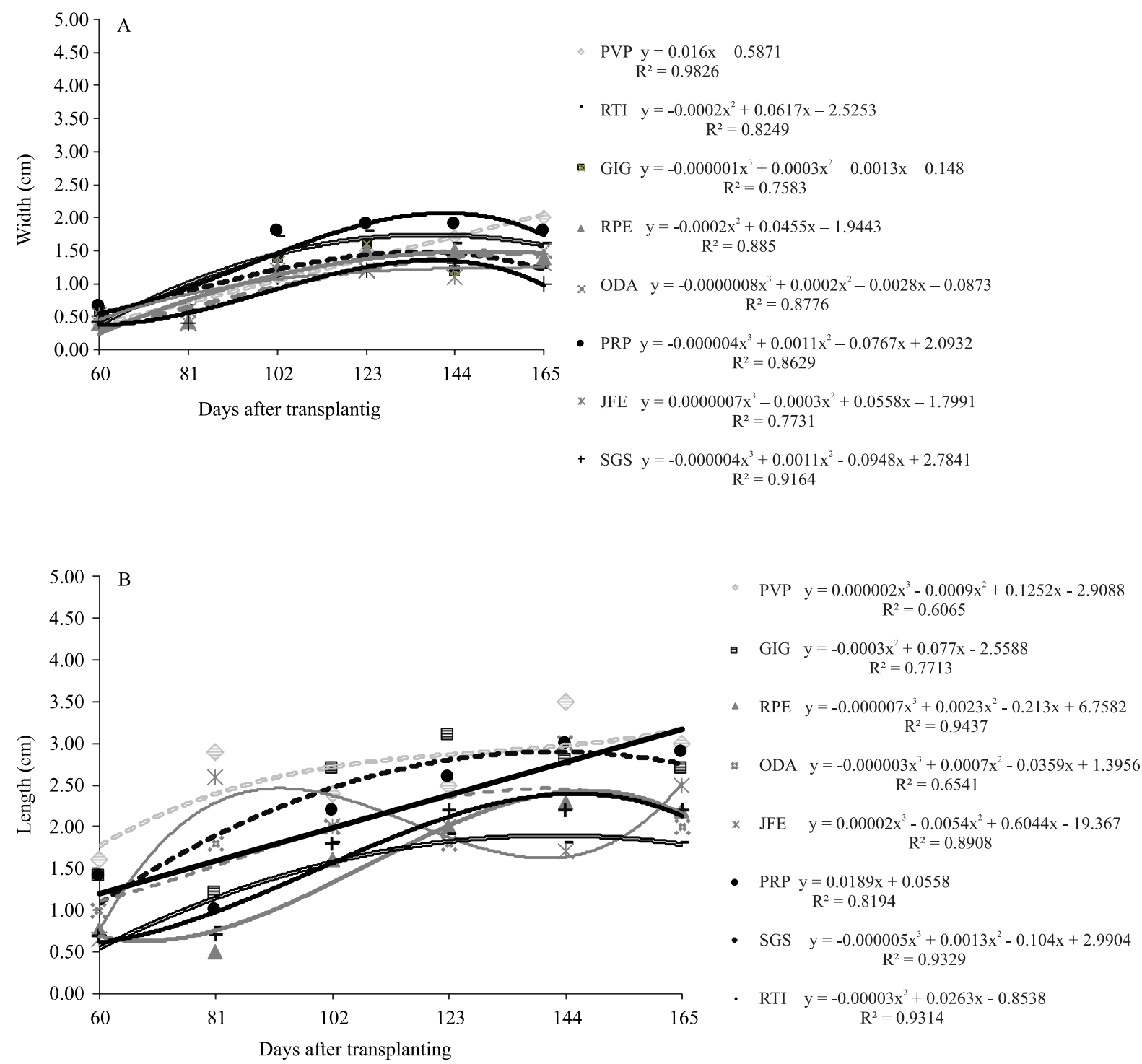

Figure 1. Development in leaf width (A) and length (B) of eight accessions of Lippia rotundifolia grown in a greenhouse at $60,81,102,123,144$, and 165 days after transplanting in the municipality of Montes Claros, in the state of Minas Gerais, Brazil. PVP, Parque Estadual Veredas do Peruaçu; RPE, Rio do Peixe; GIG, comunidade Gigante; ODA, Área de Preservação Permanente Olhos D’água; JFE, municipality of Joaquim Felício; PRP, Parque Estadual do Rio Preto; SGS, district of São Gonçalo do Rio das Pedras; and RTI, Corrêgo do Tigre. 

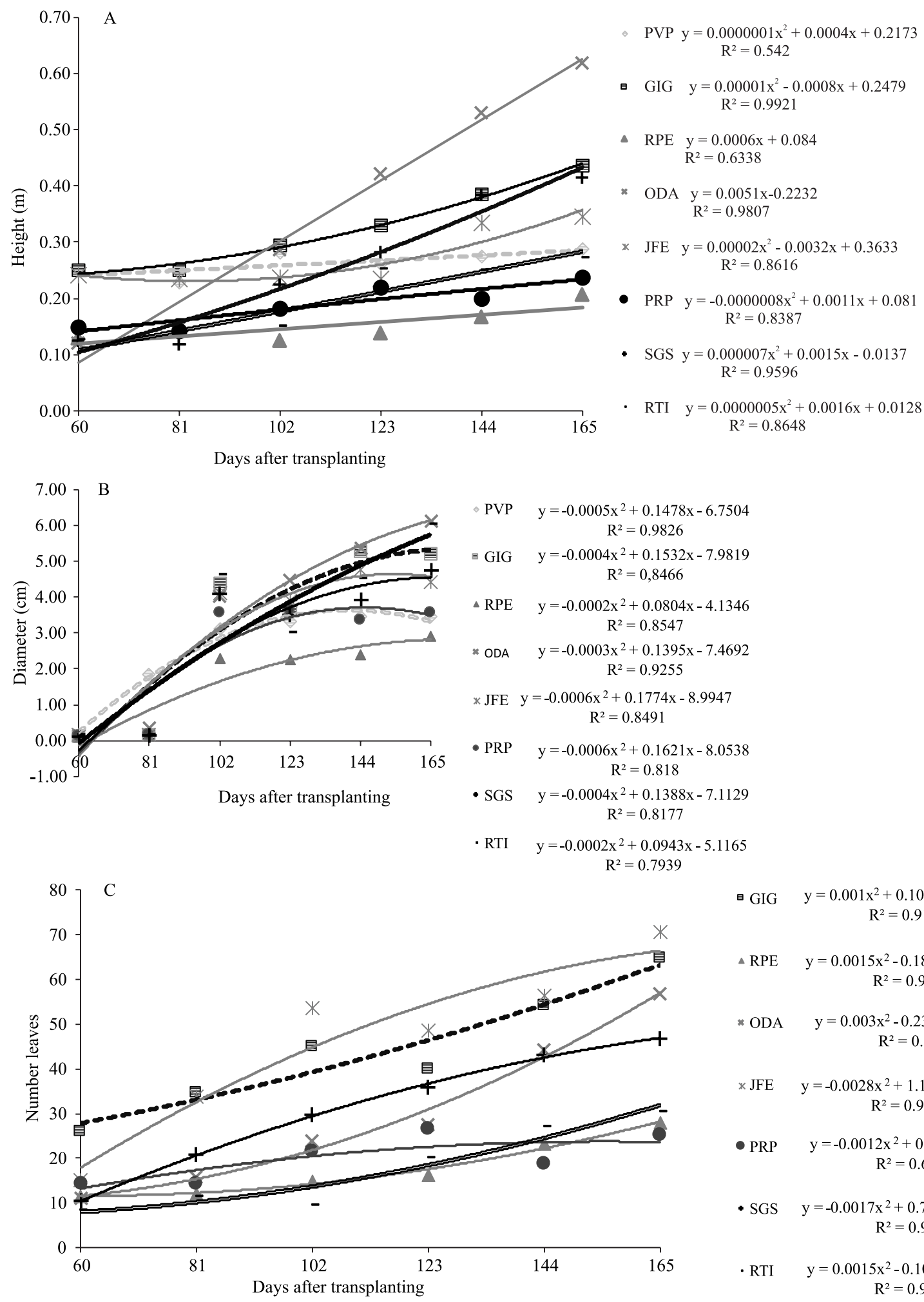

$$
\begin{array}{lc}
\text { • GIG } & y=0.001 x^{2}+0.1046 x+17.816 \\
& R^{2}=0.9137 \\
\triangle \text { RPE } & y=0.0015 x^{2}-0.1802 x+16.968 \\
& R^{2}=0.9846 \\
\text { * ODA } & y=0.003 x^{2}-0.2378 x+15.102 \\
& R^{2}=0.9881 \\
\text { * JFE } & y=-0.0028 x^{2}+1.1009 x-37.914 \\
& R^{2}=0.9103 \\
\text { - PRP } & y=-0.0012 x^{2}+0.3603 x-4.185 \\
& R^{2}=0.6209 \\
\text { - SGS } & y=-0.0017 x^{2}+0.7205 x-26.788 \\
& R^{2}=0.999 \\
\text { - RTI } & y=0.0015 x^{2}-0.1019 x+8.8189 \\
& R^{2}=0.9335
\end{array}
$$

Figure 2. Development of the aerial part (height - A, stem diameter - B, and number of leaves - C) of eight accessions of Lippia rotundifolia grown in a greenhouse at $60,81,102,123,144$, and 165 days after transplanting in the municipality of Montes Claros, in the state of Minas Gerais, Brazil. PVP, Parque Estadual Veredas do Peruaçu; GIG, comunidade Gigante; RPE, Rio do Peixe; ODA, Área de Preservação Permanente Olhos D’água; JFE, municipality of Joaquim Felício; PRP, Parque Estadual do Rio Preto; SGS, district of São Gonçalo do Rio das Pedras; and RTI, Corrêgo do Tigre. 
that the greater the diameter, the greater the biomass accumulation of plants. Moreover, since all evaluated accessions were obtained by vegetative propagation, the cuttings presented different reserve levels.

Taking the number of leaves into consideration, the RTI accession also showed the lowest performance for both the cutting and regrowth stages. In the first stage, the number of leaves did not exceed 30 until the last evaluation at 165 days (Figure $2 \mathrm{C}$ ). In the second, the emission of leaves in response to regrowth was only observed in the first fortnight (Figure $3 \mathrm{C}$ ). A different behavior was verified for JFE, which presented the highest number of leaves, ranging from 53 to 70 per plant, with a progressive growth from 102 days of cultivation (Figure $2 \mathrm{C}$ ). However, this accession, together with SGS, did not respond positively to cutting, maintaining an average of 40 leaves throughout the evaluation period (Figure $3 \mathrm{C}$ ). The difference between these two last accessions is that the number of leaves tended to reduce progressively for JFE, but to decrease at 102 days and reestablish at 144 days after cutting for SGS. ODA presented an average of 95 leaves throughout the periods after cutting. The opposite was observed for PRP, which showed a good development at 102 and 123 days after transplanting, as well as for RPE, which presented a progressive growth. During regrowth, these two accessions continued to gradually emit leaves in the same evaluation periods. Differently from the ODA accession that showed stability, SGS and JFE were characterized by a reduction in the number of leaves over time.

Regarding biomass, the JFE, ODA, SGS, and PRP accessions presented the highest values of fresh mass, between 95.95 and $113.0 \mathrm{~g}$ (Table 2). The highest dry mass values of 14.09 and $13.3 \mathrm{~g}$ were obtained for GIG and JFE. Out of all accessions, RTI presented the lowest biomass, with $50.0 \mathrm{~g}$ fresh mass and $9.92 \mathrm{~g}$ dry mass.

Regarding essential oil content, significant differences were observed between the accessions. The average content of this parameter was $0.76 \%$. The SGS accession showed the highest yield of $2.2 \%$, whereas PVP and JFE had the lowest ones of 0 and $0.35 \%$, respectively (Table 2 ). The oil yield of the RTI and RPE accessions was similar, being of 0.40 and $0.54 \%$, respectively, while that of the other accessions was above $0.60 \%$, ranging from 0.61 to $0.91 \%$ for ODA, GIG, and PRP. This compatibility in oil content is due to the genetic similarity observed through the molecular structure analysis, in which these accessions were gathered in the same group by genetic proximity (Meira et al., 2019b). According to Jannuzzi et al. (2011), a yield of $0.5 \%$ essential oil is considered satisfactory for $L$. alba. Therefore, the levels found in the present study are high enough to represent an aromatic plant species and may be promising to meet possible market demands.

Leaf size and essential oil content were correlated: the highest oil content was obtained by accessions with median leaves (GIG, RPE, ODA, JFE, PRP, and SGS), and the lowest one, by the accession with longer leaves (PVP). This same observation was made for L. alba by Jannuzzi et al. (2011), who found that the accessions with a greater leaf area had lower oil contents. However, oil content was not related to a higher shoot production since the JFE accession had the highest number of leaves but the lowest essential oil content. Furthermore, there was no significant difference among PVP, RTI, and RPE, which presented the same profile for phytomass production and a small variation in oil content (Table 2). According to Taiz et al. (2017) and Selmar \& Kleinwächter (2013), this result could be attributed to the conditions under protected

Table 2. Fresh and dry matter of the aerial part and essential oil yield of accessions of Lippia rotundifoia 165 days after transplanting in a greenhouse in the municipality of Montes Claros, in the state of Minas Gerais, Brazil ${ }^{(1)}$.

\begin{tabular}{lccc}
\hline Accession $^{(2)}$ & \multicolumn{3}{c}{ Treatment } \\
\cline { 2 - 4 } & Fresh mass $(\mathrm{g})$ & Dry matter $(\mathrm{g})$ & Essential oil yield (\%) \\
\hline PVP & $50.57 \mathrm{C}$ & $11.66 \mathrm{~B}$ & $0.297 \mathrm{C}$ \\
ODA & $99.25 \mathrm{AB}$ & $12.07 \mathrm{~B}$ & $0.789 \mathrm{~B}$ \\
RTI & $50.00 \mathrm{C}$ & $9.92 \mathrm{BC}$ & $0.403 \mathrm{C}$ \\
GIG & $74.31 \mathrm{~B}$ & $14.09 \mathrm{~A}$ & $0.617 \mathrm{~B}$ \\
SGS & $97.87 \mathrm{AB}$ & $11.64 \mathrm{~B}$ & $2.197 \mathrm{~A}$ \\
RPE & $52.77 \mathrm{C}$ & $10.00 \mathrm{~B}$ & $0.540 \mathrm{BC}$ \\
JFE & $95.95 \mathrm{AB}$ & $13.30 \mathrm{~A}$ & $0.348 \mathrm{C}$ \\
PRP & $113.00 \mathrm{~A}$ & $10.47 \mathrm{~B}$ & $0.907 \mathrm{~B}$ \\
\hline Average & 79.22 & 11.64 & 0.76 \\
CV $(\%)$ & 35.00 & 22.00 & 26.00 \\
\hline
\end{tabular}

${ }^{(1)}$ Means followed by equal letters do not differ significantly by Tukey's test, at 5\% probability. (2)PVP, Parque Estadual Veredas do Peruaçu; ODA, Área de Preservação Permanente Olhos D’água; RTI, Corrêgo do Tigre; GIG, comunidade Gigante; SGS, district of São Gonçalo do Rio das Pedras; RPE, Rio do Peixe; JFE, municipality of Joaquim Felício; and PRP, Parque Estadual do Rio Preto. CV, coefficient of variation. 
cultivation, which lead to a higher increase in plant primary metabolites during the vegetative stage.

For the best production time and essential oil content, it is necessary to evaluate production considering the phenological cycle of each accession (Souza et al., 2014). Besides phenology, the diversity among genotypes may also explain the differences found in the evaluated parameters (Hartl \& Clark, 2010), especially since the environmental factors were controlled under greenhouse conditions. Likewise, Tavares et al. (2005) inferred that the differences between plants are due to the plasticity expressed by the used accessions, since, in a natural environment, the species occurs under different climatic conditions, such as altitude ranging from 690 to $1,020 \mathrm{~m}$, precipitation from 700 to 1,600 $\mathrm{mm}$, and temperature from 18 to $24^{\circ} \mathrm{C}$ (Table 1) (Meira et al., 2019b). Moreover, considering that the evaluated species has a low nutritional requirement and grows in soil with low to very low levels of physicochemical attributes, high acidity, and clayey texture (Ribeiro et al., 1999), it is believed that the cultural treatments applied in the present work were efficient to obtain the observed results.

This study showed that the exploration of the aerial part of the plant to obtain secondary metabolites, such as essential oil under cutting management, ensures a good amount of cultivated material. In addition, knowing the cutting time of each accession maintains the integrity of the species without compromising its populations, since it is endemic and affected by anthropic action.

\section{Conclusions}

1. All eight evaluated accessions of Lippia rotundifolia show variation in growth, regrowth, and essential oil content.

2. The accession from the municipality of Joaquim Felício, in the state of Minas Gerais, Brazil, stands out for emission of leaves, with a better development at 165 days after transplanting, whereas the accessions from Rio do Peixe and Parque Estadual do Rio Preto respond well to regrowth at 102 and 123 days after cutting, respectively.

3. The accession from the district of São Gonçalo do Rio das Pedras has a high essential oil yield of 2.2\%, and that from Parque Estadual Veredas do Peruaçu, a low one of $0.3 \%$.

\section{Acknowledgments}

To Coordenação de Aperfeiçoamento de Pessoal Nível Superior (Capes), for financing, in part, this study (Finance Code 001); to Conselho Nacional de Desenvolvimento Científico e Tecnológico (CNPq), for financial support (process number 152341/2016-1); and to Fundação de Amparo à Pesquisa do Estado de Minas Gerais (Fapemig), for financial support (process number APQ-01010-18).

\section{References}

AZEVEDO, I.L.; MARTINS, E.R.; ALMEIDA, A.C. de; NOGUEIRA, W.C.L.; FARIA FILHO, D.E. de; SANTOS, V.K.F. do R.; LARA, L.J.C. Use of Lippia rotundifolia and Cymbopogon flexuosus essential oils, individually or in combination, in broiler diets. Revista Brasileira de Zootecnia, v.46, p.13-19, 2017. DOI: https://doi.org/10.1590/S1806-92902017000100003.

CABRAL, R.D.C.; MELO JUNIOR, J.C.F. de; MATILDESILVA, M. Plasticidade morfoanatômica foliar em Smilax campestris (Smilacaceae) em gradiente ambiental de restinga, SC, Brasil. Hoehnea, v.45, p.173-183, 2018. DOI: https://doi.org/10.1590/2236-8906-65/2017.

COSTA, P.S.; SOUZA, E.B. de; BRITO, E.H.S. de; FONTENELLE, R.O. dos SANTOS. Atividade antimicrobiana e potencial terapêutico do gênero Lippia sensu lato (Verbenaceae). Hoehnea, v.44, p.158-171, 2017. DOI: https://doi.org/10.1590/22368906-68/2016.

DUARTE, E.F.; OLIVEIRA JÚNIOR, E.D.; BIGARELLI, L.F.G.; ALMEIDA, C.S.; SILVA, L.C.; ASSIS, S.R.F. Enraizamento de estacas d produção de biomassa de Lippia alba (Mill) N. E. Brow. (Verbenaceae). Revista Científica Eletrônica de Agronomia, ano1, p.1-4, 2002.

HARTL, D.L.; CLARK, A.G. Princípios de genética de populações. 4.ed. Porto Alegre: Artmed, 2010. 660p.

HSIE, B.S. de; BUENO, A.I.S.; BERTOLUCCI, S.K.V.; CARVALHO, A.A. de; MARTINS, E.R.; PINTO, J.E.B.P. Growth regulators induced shoot regeneration and volatile compound production in Lippia rotundifolia Cham., a threatened medicinal plant. Industrial Crops and Products, v.137, p.401-409, 2019. DOI: https://doi.org/10.1016/j.indcrop.2019.05.050.

IBGE. Instituto Brasileiro de Geografia e Estatística. Portal de Mapas do IBGE. 2021. Available at: $<$ https://portaldemapas.ibge. gov.br/portal.php\#homepage> Accessed on: Ago 42021.

JANNUZZI, H.; MATTOS, J.K.A.; SILVA, D.B.; GRACINDO, L.A.M.; VIEIRA, R.F. Avaliação agronômica e química de dezessete acessos de erva-cidreira [Lippia alba (Mill.) N.E.Brown] - quimiotipo citral, cultivados no Distrito Federal. Revista Brasileira de Plantas Medicinais, v.13, p.258-264, 2011. DOI: https://doi.org/10.1590/S1516-05722011000300002.

KUMAR, S.; JENA, S.N.; NAIR, N.K. ISSR polymorphism in Indian wild Orange (Citrus indica Tanaka, Rutaceae) and related 
wild species in North-east India. Scientia Horticulturae, v.123, p.350-359,2010. DOI:https://doi.org/10.1016/j.scienta.2009.10.008.

MARTINS, S.C.V.; DETMANN, K.C.; REIS, J.V. dos; PEREIRA, L.F.; SANGLARD, L.M.V.P.; ROGALSKI, M.; DAMATTA, F.M. Photosynthetic induction and activity of enzymes related to carbon metabolism: insights into the varying net photosynthesis rates of coffee sun and shade leaves. Theoretical and Experimental Plant Physiology, v.25, p.62-69, 2013. DOI: https://doi.org/10.1590/ S2197-00252013000100008.

MEIRA, M.R.; MARTINS, E.R.; FONSECA, F.S.A. da. Chemical diversity of the volatiles of Lippia rotundifolia Cham. (Verbenaceae) in Minas Gerais, Brazil. Anais da Academia Brasileira de Ciências, v.91, e20180498, 2019a. DOI: https://doi.org/10.1590/0001-3765201920180498.

MEIRA, M.R.; MARTINS, E.R.; RESENDE, L.V. Genetic diversity of Lippia rotundifolia Cham. in Minas Gerais, Brazil. Acta Scientiarum. Biological Sciences, v.41, e42754, $2019 \mathrm{~b}$. DOI: https://doi.org/10.4025/actascibiolsci.v41i1.42754.

MEIRA, M.R.; MARTINS, E.R.; RESENDE, L.V. Physical and physiological quality of the Lippia rotundifolia seeds according to the osmotic conditioning and electrical conductivity. Ciência Rural, v.46, p.2096-2102, 2016. DOI: https://doi.org/10.1590/0103$8478 \mathrm{cr} 20150633$.

RESENDE, C.F. de; BIANCHETTI, R.E.; OLIVEIRA, A.M.S. de; BRAGA, V.F.; PEIXOTO, P.H.P. In vitro propagation and acclimatization of Lippia rotundifolia, an endemic species of Brazilian Campos Rupestres. Revista Ciência Agronômica, v.46, p.582-589, 2015. DOI: https://doi.org/10.5935/18066690.20150041 .

RIBEIRO, A.C.; GUIMARÃES, P.T.G.; ALVAREZ, V.V.H. (Ed.). Recomendações para o uso de corretivos e fertilizantes em Minas Gerais: $5^{\text {a }}$ aproximação. Viçosa: Comissão de Fertilidade do Solo do Estado de Minas Gerais, 1999. 359p.

RIBEIRO JÚNIOR, J.I. Análises estatísticas no SAEG. Viçosa: Universidade Federal de Viçosa, 2001. 301p.

SALIMENA, F.R.G.; MÚLGURA, M.E. Notas taxonômicas em Verbenaceae do Brasil. Rodriguésia, v.66, p.191-197, 2015. DOI: https://doi.org/10.1590/2175-7860201566110.

SANTOS, M.R.A. dos; INNECO, R.; FERNANDES, C. de F. Efeitos da altura de corte de erva-cidreira (Lippia alba) na produção de biomassa e óleo essencial. Porto Velho: Embrapa Rondônia, 2006. 10p. (Embrapa Rondônia. Boletim de pesquisa e desenvolvimento, 35).
SANTOS, H.G. dos; JACOMINE, P.K.T.; ANJOS, L.H.C. dos; OLIVEIRA, V.Á. de; LUMBRERAS, J.F.; COELHO, M.R.; ALMEDIA, J.A. de; ARAÚJO FILHO, J.C. de; OLIVERIA, J.B. de; CUNHA, T.J.F. Sistema brasileiro de classificação de solos. 5.ed. rev. e ampl. Brasília: Embrapa, 2018. 356p.

SELMAR, D.; KLEINWÄCHTER, M. Stress enhances the synthesis of secondary plant products: the impact of stressrelated over-reduction on the accumulation of natural products. Plant \& Cell Physiology, v.54, p.817-826, 2013. DOI: https://doi.org/10.1093/pcp/pct054.

SOUSA, S.M.; PIERRE, P.M.O.; TORRES, G.; DAVIDE, L.C.; VICCINI, L.F. Relationship between pollen morphology and chromosome numbers in Brazilian species of Lippia L. (Verbenaceae). Anais da Academia Brasileira de Ciências, v.85, p.147-157, 2013. DOI: https://doi.org/10.1590/S000137652013005000010 .

SOUZA, D.S.; ALMEIDA, A.C.; ANDRADE, V.A.; MARCELO, N.A.; AZEVEDO, I.L.; MARTINS, E.R.; FIGUEIREDO, L.S. Atividade antimicrobiana do óleo essencial de Lippia origanoides e Lippia rotundifolia frente a enterobactérias isoladas de aves. Arquivo Brasileiro de Medicina Veterinária e Zootecnia, v.67, p.940-944, 2015. DOI: https://doi.org/10.1590/1678-4162-7580.

SOUZA, G.S. de; SILVA, J. dos S.; OLIVEIRA, U.C. de; SANTOS NETO, R.B. dos; SANTOS, A.R. dos. Crescimento vegetativo e produção de óleo essencial de plantas de alecrim cultivadas sob telas coloridas. Bioscience Journal, v.30, p.232-239, 2014. Suppl.1.

SOUZA, M.F. de; GOMES, P.A.; SOUZA JUNIOR, I.T. de; FONSECA, M.M.; SIQUEIRA, C. da SILVA.; FIGUEIREDO, L.S. de; MARTINS, E.R. Influência do sombreamento na produção de fitomassa e óleo essencial em alecrim-pimenta (Lippia sidoides Cham.). Revista Brasileira de Biociências, v.5, p.108-110, 2007. Supl.2.

TAVARES, E.S.; JULIÃO, L.S.; LOPES, D.; BIZZO, H.R.; LAGE, C.L.S.; LEITÃO, S.G. Análise do óleo essencial de folhas de três quimiotipos de Lippia alba (Mill.) N. E. Br. (Verbenaceae) cultivados em condições semelhantes. Revista Brasileira de Farmacognosia, v.15, p.1-5, 2005. DOI: https://doi.org/10.1590/ S0102-695X2005000100002.

TAIZ, L.; ZEIGER, E.; MØLLER, I.M.; MURPHY, A. Fisiologia e desenvolvimento vegetal. 6.ed. Porto Alegre: Artmed, 2017. $888 \mathrm{p}$. 